\title{
WASTE AND DIRT IN SHORT FOLKLORE FORMS
}

\section{SAŠA BABIČ}

The article examines the concept and metaphorical meaning of waste and dirt in short folklore forms, including archival material (phrasemes, proverbs, and beliefs) and also internet memes as a new, contemporary folklore form. Waste and dirt are traditionally conceptually linked to metaphors of unwanted, used, lower-quality, or even immoral. Slovenian proverbs and phrasemes, on the other hand, do not thematize waste management or handling dirt; only beliefs show some part of this. New forms, on the other hand, emphasize environmental pollution directly, using concepts of waste and pollution combined in words and images intended to persuade the viewer or recipient to change their behavior into environmentally responsible behavior. Waste and dirt reveal themselves as important metaphorical elements, as well as a contemporary topic for new folklore genres.

Keywords: proverb, belief, folklore, meme, waste
Članek se posveča konceptu in metaforičnemu pomenu smeti in umazanije v folklornih obrazcih, predvsem v arbivskem gradivu (frazemi, pregovori, verovanja) kot tudi vinternetnih memih kot novi, sodobni folklorni formi. Smeti in umazanija sta konceptualno vezana na metafore neželenega, rabljenega, nižje kvalitete ali celo nemoralnega. Po drugistrani slovenski pregovori in frazemi ne ubesedujejo ravnanja $z$ odpadki in umazanijo, le v verovanjih je nekaj malega nakazano. Po drugi strani pa nove oblike neposredno poudarjajo okoljsko onesnaženje: uporaba koncepta smeti in onesnaženosti je kombinirana $z$ besedami in podobami, da bi vplivala na naslovnika $z$ namenom spremeniti njegovo/njeno vedenje $v$ okoljsko odgovorno.

Smeti in umazanija se razkrivata kot pomembna metaforična elementa in sta tudi sodobna tema novih folklornih žanrov. Ključne besede: pregovor, verovanje, slovstvena folklora, mem, odpadki

\section{INTRODUCTION}

Waste is a mirror of humanity (Knechtel 2007: 9), not only in everyday life but also in language. Language serves to preserve and carry culture (Tolstoi 1995; Bartmiński 2005; Tolstaya 2015); it is extremely flexible and can express anything that crosses our minds with the use of metaphors. Inserting denominations of our surroundings into our conceptual constructs allows us to create further, broader, or figurative meanings of them. Because language use is always socially contextualized, language serves as a carrier of external information about images, values, and social relationships that label a certain community (Petrovič 2010). It is, as Laura Ahearn pointed out (2017), possible to speak about the inseparability of language, culture, and social relations. Verbalizing metaphors and metonyms with terms for waste reveals the conceptual perception of dirt and waste, and cleanliness and order-both literally and in figurative language.

This article focuses on short folklore forms as folklore artefacts and language entities within the diachronic conceptual world. Language shaped in different forms and passed on from one generation to another preserves social concepts and offers deeper insights while 
telling stories about social views on specific phenomena. Taking into account especially negative, neglected, or taboo topics or word units can bring new insights into the society; for example, terms such as garbage, trash, shit, and so on.

\section{THEORETICAL FRAMEWORK}

Linguistic anthropology studies culture through the "meaning as culture" approach: linguistic meaning is determined by the cultural context in which the language occurs; these cannot be separated from one other (Forrester 1996: 48). This approach is seen as the foundational framework of a worldview. As Frawley stated, "Language, culture and thought are all mirrors of each other ... so it is possible to read thought off language, and language off culture because linguistic distinctions reflect cultural distinctions, which in turn generate distinctions in thought" (1992: 46). Language use can be observed from three theoretical fields within linguistic anthropology: indexicality (words are indexically connected to an object or worldview), performance (the actual use of language, attention, perception, and memory that have to be in use so that the speaker can effectively and independently use the abstract knowledge), and participation (the speaker as a social participant; Duranti 1997: 14-21). Speech is defined as a social activity that always contains more than just linguistic expressions: to be a speaker of a certain language means being part of the society. A competent speaker can be part of broader social activities that are organized and interpreted within the framework of culture, which is broader than the things that can be seen and touched at any given moment. A link with this broad world — whether real or imaginary-is created through performative power, which comes through its indexicality (Babič 2017).

Language use can only be understood when it is integrated within the patterns of everyday actions (Forrester 1996: 45). The meaning is located in the function of sharing information passed back and forth between people (Wittgenstein 1953: 180). Words only obtain their meaning in the context of thought and life: "Context and use determine the meaning, and the meaning of an expression is a function of its use in a particular context" (Forrester 1996: 45). George Lakoff and Mark Johnson introduced a way of studying culture through concepts that are expressed through metaphors. These concepts provide the structure for how people understand and relate to the outer world (Lakoff and Johnson 1980: 3). It could be claimed that our everyday realities are defined within our conceptual system, which is why metaphors are pervasive in everyday life-both in thought and action and, consequently, in language. Linguistic meaning precedes and enters the use context as speakers bring this meaning with them into the context of communication. The context and use are thus relevant to the meaning because speakers have a prior conceptual structure (Frawley 1992: 54), which is also mirrored in metaphors, which are not linguistic phenomena, but cognitive ones (Dancygier and Sweetser 2014: 22). Metaphors in these structures are linked to understanding and experiencing one kind of phenomenon in the sense of 
another kind (Lakoff and Johnson 1980: 27); they emerge from (cross)cultural patterns in everyday experience (Dancygier and Sweetser 2014: 8). In this respect, metaphors are defined by a lexical frame:

a lexical frame is a frame paired with a lexical item or lexical items that represent it. . . . an expression referring to some aspect of a frame structure gives conceptual access to the entire structure, so that evoking one aspect of a frame provides access to the entire frame, and individual frame components are understood in the context of the entire frame. (Dancygier and Sweetser 2014: 17)

This presumption does not take into consideration the individual understanding of concepts (or idiolects): personal understandings of waste, dirt, and hygiene probably vary, although the inclusion of these in language represents a general view. Ethnolinguistic approaches also offer insight into the language perception of the world of dirt and cleanliness. The broad definition of ethnolinguistics (Lublin School) occupies all aspects of examining language as a social phenomenon (Bartmiński 2005: 159-161). Ethnolinguistic methods are, at a certain point, similar to linguistic anthropology, and can be used to explain how the collective consciousness and history are reflected in language, and how the concept of reality is manifested in cultural texts. Ethnolinguistics introduces a "world map," with concepts and stereotypes that are created around various objects that have an important role in the modern worldview: conceptualizations about the world and human beings, basic understandings that show specifics of human beings and their existence, their relationship with the world, and the most important conditions of their existence; a language world map shows all the aspects of an individual's worldview and imaginings (Balašova 2004). The ethnolinguistic approach offers insight into collective concepts and stereotypes (as images and opinions) on dirt and waste from folklore material as the focus loci of this paper; more specifically, it examines short folklore forms as a form of condensed collective concepts.

Short folklore forms are short, more-or-less fixed texts that are passed from one generation to another, or at least remain in the language long enough to become part of the mental dictionary; they are often described as "traditional." These repeated traditional expressions with an intentional pragmatic aim contain diverse cultural viewpoints in different dialogues. This category includes greetings, swear words, proverbs, phrasemes, riddles, and so on. These short folklore forms are understood as artifacts and cultural phenomena that include knowledge, belief, art, morals, law, custom, and any other capabilities and habits acquired by an individual as a member of society; these forms serve as bases for collective social identification (Georges and Jones 1995: 159). They are also entities that are configurable into generics and typesets and are transmissible through space, making similarities and differences among individual examples of folklore the foci of inquiry. These genres of short folklore forms are mostly used in everyday language and are not seen as particularly noteworthy (even in collections they are often written down just as material collected on 
the side). Nevertheless, these genres contain collective images, concepts, and stereotypes that can describe the general perception of the phenomena because they are language constructions that are accepted into the society's language and cultural codes, and that are formed through time by its location and mentality (Green 1998). The meaning of the phenomenon can be examined especially through the metaphoric use of the denomination in different environments, thus revealing a broader picture of the stereotype.

Folklore, and short folklore forms within it, fulfils symbolic and interrogative needs in culture (Oring 1976: 68) and is related to other aspects of the cultures to which it belongs. Therefore, folklore serves as an important source of cultural knowledge and understanding. Short folklore forms are culturally coded, describing and referring to experiences and symbols that are distinctive to individual groups and subgroups. As a part of folklore, they mirror both contemporary and "forgotten" ways of life. Short folklore forms are used to express disapproval, expected behavior, or social approval of those that conform to expectations. Proverbs, for example, can be "highly effective in exercising social control" (William Bascom, cited in Georges and Jones 1995: 189).

This article focuses on dirt, waste, and cleanliness as metaphorical elements in Slovenian short folklore forms to understand how these concepts are widely applied to everyday life. In Slovenian society, dirt is a matter of aesthetics, hygiene, and etiquette, which becomes serious only when it creates social embarrassment (Douglas 1984 [1966]: 74). Dirt mostly denotes disorder, although absolute dirt does not exist: it exists only in the eye of the beholder. Therefore, dirt is a strike against order, whereas keeping the environment clean primarily means arranging the environment and adapting it to certain perceptions (Douglas 1984 [1966]: 11). However, in the large structured repository of conceptual metaphors, The Metanet Metaphor Wiki, ${ }^{1}$ one can also read a complementary dimension, in which cleanliness is purity and purity is morality. ${ }^{2}$ Dirt as an opposition to clean is used in Slovenian short folklore forms to describe something unwanted and lower on the scale of social values, something that does not go along with the concept of normality that is thought of as a redundant phenomenon. In other words: even metaphorically, dirt denotes disorder and a strike against order, and implicitly also as immoral versus moral (see Lizardo 2012).

\section{METHODOLOGY}

Images of dirt and cleanliness were examined through the formulaic language of selected Slovenian short folklore forms (phrasemes, proverbs, swear words, and beliefs) from the

1 This is a project of the metaphors and frames repository, which is managed by a linguistics team (George Lakoff and others) from the University of California, Berkeley. https://metaphor.icsi.berkeley.edu/pub/en/index.php/MetaNet_Metaphor_Wiki

2 Source inference is cleansing, target entailment is purifying. https:/metaphor.icsi.berkeley.edu/pub/ en/index.php/Metaphor:PURITY_IS_CLEANLINESS 
collections in the ZRC SAZU Institute of Slovenian Ethnology. ${ }^{3}$ All the units are from the ISN collection, which was built in the second half of the nineteenth and the twentieth century from ethnographic fieldwork and transcribing recognized folklore units from newspapers, in which they were understood as artefacts and cultural phenomena. The collection contains over sixty thousand units and is maintained in Excel format. Some units are not used in language anymore and are only relics from prior times, whereas other are actively used and are quite often heard or read.

The selected short folklore forms for this research were found with a search engine in Excel using the words with the meanings 'dirt' and 'clean'. The units selected were taken as examples of metaphors built on words and concepts of waste and dirt, regardless of their use. The following research questions were employed in this observation of the concepts of dirt or cleanliness: What is clean and what is dirty in conceptual sense? What are the connotations that these short folklore forms carry? The analysis of the material is conceptual and shows that there are two distinct but comparable conceptual domains (or spaces) that may be linked by a cross-domain mapping (Steen et al. 2010: 9).

Contemporary material has also been included in this study, which takes into consideration a small collection of internet memes. The main categories of memes thematizing waste management and pollution were detected using the Google search engine to find keywords. The internet memes selected are just a sampling of the phenomenon, which show that the topic is ripe for further research. The categories shown here are a starting point for obtaining an overview.

\section{ANALYSIS OF SHORT FOLKLORE FORMS}

Polluting the environment not only denotes the physical waste that is produced and discarded in the course of daily life. In Slovenian, polluting is also conceptually linked to behavior, like noise and speech: we can umazati si roke 'get our hands dirty', our words can be sranje 'trash or shit', and we can imeti umazane misli 'have dirty thoughts'. After using umazan jezik 'dirty (or even) devilish language', one has to wash his or her mouth out with soap so that the verbal dirt is washed out (this used to be a very common educational method); a dirty mouth can then biti čist kot solza 'be as pure as tears (i.e., the driven snow)' once again. For starters, these examples show how undesirable speech acts or simply thoughts can be interpreted as dirty and presumably harmful, or as a strike against order. Not only actions but also thoughts or expressing them can be marked as a strike against the society or moral rules as a whole. Already at first glance it is apparent that the adjective dirty or substantives like trash, garbage, and waste are conceptually linked in Slovenian with unwanted expressions or topics, or unexpected vocabulary; they are conceptually connected with 
redundant, unwanted verbal activity or with a person with unacceptable behavior: izmeček 'scum(bag)'. The image stereotype of unclean is usually a muddy or somehow visually dirty object, which is transferred into a figurative image of a person's action or speech: even one of the educational methods of washing a child's mouth out with soap (when a child has been shouting or speaking inappropriately) shows that the figurative dirt is conceptual physical dirt and can be (physically) removed.

\section{THE BODY AND DIRT}

Connecting actions and dirt on a body exposes the hands: the phraseme umazati si roke 'to get one's hands dirty' denotes an action that is negative and dishonorable, and implies that the hands need to be cleaned after undesirable actions. Dirt that cannot be removed is blood: imeti kri na rokah 'to have blood on one's hands' is a phraseme denoting that one has killed a living being. The opposite phraseme imeti ciste roke 'to have clean hands' implies that one is not guilty of a negative or dishonorable action. This phraseme is usually in dialogue with its opposite (to dirty one's hands) when proving a false assumption about someone's guilt. The image behind this phraseme is that one never got his/her hands dirty; their innocence was proven from the start. Thus, even though the dirty hands imply that they need to be cleaned, it seems that when people get "dirt on their hands" they can never be clean again. The phraseme roka roko umije 'one hand washes the other', with the English equivalent of "You scratch my back and I'll scratch yours" implies washing hands as hiding the dirt (or guilt), or also doing a favor in dishonorable circumstances. The image of washing and being clean can be seen only in the phraseme oprati (koga) krivde 'to wash away the blame', where the guilt has been mistakenly assigned to someone. Hence, the "washing" does not denote correcting any kind of unacceptable action, but just correcting wrong assumptions by others.

Not only the body is involved in the metaphorical language connected with dirt. The metaphorical level of dirt includes also the world of intimacy and housekeeping. The private sphere of life that is not supposed to be shown publicly and bragged about is laundry: prati svoje umazano perilo v javnosti 'to wash one's dirty linen in public'. Dirty linen was supposed to be inappropriate to be shown or even discussed. Private matters that one is not supposed to be proud of are also like dirty linen: these range from misunderstandings to public gossip and blatenje 'smearing'. The proverb thematizing a similar meaning is: Iz hiše ne nosi smeti, pa bo manj besedi 'Don't carry trash out of the house, and people won't talk so much'. The metaphor of dirt and waste in both paremiological units is linked to private matters that are shameful and lead to gossip: both of them suggest not discussing private matters outside of the intimacy of the home. The metaphor is an image from householding that places dirt and cleanliness in opposition, although the conceptual metaphor stays attached to the verbal act of revealing one's private business. 
On the other hand, proverbs thematizing content similar to wash one's dirty linen in public acknowledge that every home has some dirt inside, which usually stays behind closed doors: Za vrati smeti ostajajo 'The trash stays behind the door'. Waste and dirt as a metaphor for one's shameful characteristics and personal details leads to the proverb's borrowed image of the realistic situation that dust and dirt — as something undesirable — stays in corners and behind the doors.

Bodily waste is also understood as undesirable dirt that can pollute cleanliness: pljuvati $v$ lastno skledo 'spitting in one's own bowl', with the meaning of harming oneself is the image of spoiling a bowl with a bodily excretion that ruins the quality of food or at least makes the bowl unclean. Phrasemes that denote not caring about someone or something also belong in the same category of bodily excretion: kdo se poserje/poščije se na koga 'who gives a shit/to piss on someone', because even the particular words chosen are connoted as vulgar. By metaphorically putting our excretions on others and making them dirty, we show their absolute unworthiness: what could be more unimportant than things or people that we ignore even to the point of excreting on them? On the other hand, what an insult it is to conceptually load the thing or a person with our most disgusting, smelly, dirty material.

Another group of folklore forms that uses terms for bodily excretions is also swear words: verbalizing drek, sranje 'shit ${ }^{4}$ in Slovenian is not rare, and always denotes something unpleasant, usually a problem or pain or something similar; that is, something that ruined our pleasant, "clean" world.

Words borrowed from the lexicon of hygiene and excretion are usually used for swear words or for insulting language. They are part of a person's normal activities, connected with everyday life and expressions, but at the same time these verbal acts are punished by having one's mouth washed out with soap.

\section{POLLUTION, DUMPS, AND WASTE}

Polluting and a figurative link to waste in short folklore forms is connected to more general social topics such as history, values, and economics, for example: smetišce zgodovine 'the dumping ground of history'. The meaning is about a phenomenon that is not only unimportant but also forgotten-the same as waste that has been transferred to the dump and is not in our memory anymore: it is forgotten, nonexistent.

The social perception of the poor can be read from the proverb Bogátec več ma na smetiši, kaksirota $v$ hiši 'The rich man has more in his trash than the poor man in his house', where the emphasis on the wastefulness of the rich is obvious. Also, the problem of losing one's money at a pub is thematized in a proverb, although it can be interpreted only with

4 This swear word is used in both Slovenian and English within the Slovenian cultural area, and even in German (Scheisse) on the border with Austria. In my study on swear words (Babič 2015) I noted that the expression in a foreign language (i.e. not one's native language) is perceived as less harsh than the native expression. 
deep knowledge of that aspect of history: Tako nasmeten ni noben žep, da bi ga krčmar ne ocistil 'No pocket is so full of trash that the bartender wouldn't clean it out'.

The reminder about handling waste is also metaphorically transferred to tasks that are constantly put off for a later time: Odkladki odpadki 'What we lay aside is trash' or in an even more expressive proverb, again with an emphasis on excretion Odloženo delo je $v$ drek položeno 'Delayed work is put into shit' with the meaning that nothing constantly put off can be good or worthy work. The proverb Kar burja odnese, so le smeti 'What the north wind takes away is only trash' confirms the concept that forgotten things are only waste and one need not feel sorry about them.

Collecting waste in one place is verbalized in the proverb Smeti na smeti mečejo 'They throw trash on trash', with the meaning that all similar things or persons should be put together, and if they are worthless they should be dumped.

On the other hand, the dump as a place of used up, wasted, and forgotten things can also offer something that is still useful, like in the proverb: Tudi v smeteh dobro zrnje 'Even in the trash one can find a good seed', but it is often of lower quality and worth reconsidering: Druga žena se dobi v smeteh, prva pa med rožicami na vrtu 'the second wife is from the trash, but the first one grows among flowers in the garden'.5 This huge distinction between the first and second wives - the first comes from the garden and blooming flowers, and is nice for the eye, nose, and fertility, whereas the second wife comes from the dump, used and worn out but still with some benefits - seems brutal. But a comparison between two extreme choices is rather characteristic for the expressive apparatus of proverbs.

Dirt is also implied with cleaning accessories. It is used mostly in proverbs thematizing different generations within one household, whereby the "old broom" refers to the older people, whereas the "new broom" signifies a bride that comes to the groom's house: Nova metla vse pobriše, stara pogrě́a smeti sred hiše 'The new broom sweeps up everything, while the old broom misses the dirt in the middle of the house' and Nova metla najde smet 'The new broom finds the dirt' - the first proverb can be understood that the bride is a new force in the house, whereas the second proverb can be explained that the bride always finds deficiencies in her new home. The more general meaning of the proverbs, and also the more commonly used one nowadays, is that the new thing is always better than the old one.

Waste is something that people want to get rid of, unwanted in our living space, and therefore keeping it or even measuring it when giving it away is a sign of great ungenerosity; this metaphor is used in a Slovenian proverb with hyperbole regarding weighing waste to characterize an ungenerous woman: Škrta baba tudi smeti vaga 'A stingy woman even weighs the trash'.

Proverbs that thematize relationships and self-criticism are: Kdor pred svojim pragom smeti ne vidi, jih išce pri drugih 'He who sees no dirt in front of his own doorstep looks for it at others' houses' or, from different point of view, Pri sosedu vidiš smet, pri sebi pa še

5 This proverb has not stayed in active use; it is a relic from prior times; nevertheless, it powerfully illustrates perceptions of gender, marriage, and social relations, as well as the concept of waste. 
trama ne 'You can see dirt in a neighbor's [eye], but not even a log in yours'. The proverb has many variants and is still in use in Slovenian today, with the same meaning that one might be very critical toward others but not to oneself. Dirt denotes mistakes that are noticed-again, unwanted phenomena.

Waste is also metaphorically connected to the amount of something, always with the concept of abundance (the same as shit, grain, etc.). It is used for comparative phrasemes to be as much of something as waste: Je denarja kot smeti 'As much money as trash'. The phraseme explicitly shows that waste is always in larger quantities and will never disappear; waste always was and always will be-we can count on that.

\section{CLEANLINESS AND TIDINESS}

Cleanliness is always connected with clarified situations: Priti si na čisto s ćim/glede česal koga; biti si na čistem glede česa 'to be/become clean with something/someone' — with the image of not being covered with dirt (or fog): Zrak je čist 'The air is clear'. Cleanliness in proverbs is also linked with long-lasting good relationships: Čisti računi, dobri prijatelj / Čisti računi, dolga ljubezen 'Clean accounts, good friends / Clean accounts, long love'. Clean accounts are the metaphor of good positions and relationships, of clear situations and therefore, by default, positive connotations. Just as a clean home gives a good base from which to prosper, clean situations and relationships help us function better and easier. Dirt is usually part of life that people want to avoid or hide.

\section{WASTE AND BELIEFS}

The material from the ISN collection of short folklore forms also preserves three Slovenian superstitions that are no longer alive, though they were linked to waste and waste management in the ritual year and daily routine:

Po soncezád se ne sme nosit smeti ven sez hiše 'Taking the trash out after sunset is not allowed'.

Na pustni torek mora gospodinja pred sončnim vzhodom smeti na tuj dvor vreči, da ne bo proso plevelno 'On Shrove Tuesday before sunrise, the housekeeper must throw the trash into someone else's yard so that the millet won't be full of weeds'. Ko bi bilo na pusta $v$ hiši smetno, bi bilo vse leto tako 'If the house were dirty at Carnival, so it would be the whole year around'.

Taking waste out of the house was forbidden, but with no explanation as to why. Having a clean house on major holidays is still very anchored in contemporary times in Slovenia, not only because festivity requires an exemplary space, but also because of the symbolic new start at turning points of the year, which Carnival in Slovenia is: it signifies the end of winter. 
Now that pollution has become a big problem that commands attention, newer forms of folklore have started to spread the message that not only uses waste and dirt figuratively, but also uses other expressions to point out the problem of pollution and our contribution to it. Most of these new folklore forms arose on the internet, where with the leap in new communication using social networks has spread information with extreme speed, so quickly that society is gravitating toward a society of singularity, in which anyone can get any information (Podjed 2009: 45), and this information now combines images, sounds, and text. People have started to use these characteristics to share their own worldviews and information in the accepted form of a combination of image and text, in which the picture is usually either reposted with different text and/or photoshopped, or containing famous people or characters, a phenomenon called "internet memes." Internet memes have become a universal form of spreading worldviews, and because of shared norms and values structured through cultural artefacts they can be even treated as (post)modern folklore (Shifman 2014: 14). Pollution has become one of the most important topics in world society in last decades, and thus waste and dirt are also present in these new folklore forms, which are seemingly trivial and mundane artefacts but actually reflect deep social and cultural structures. Although they spread on a micro basis, their impact is on the macro level: memes

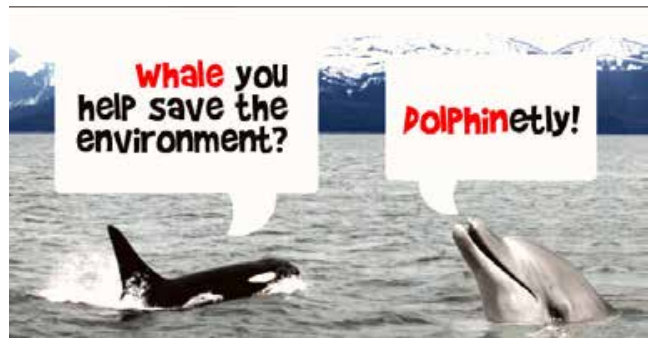

Figure 1: Wordplay with puns

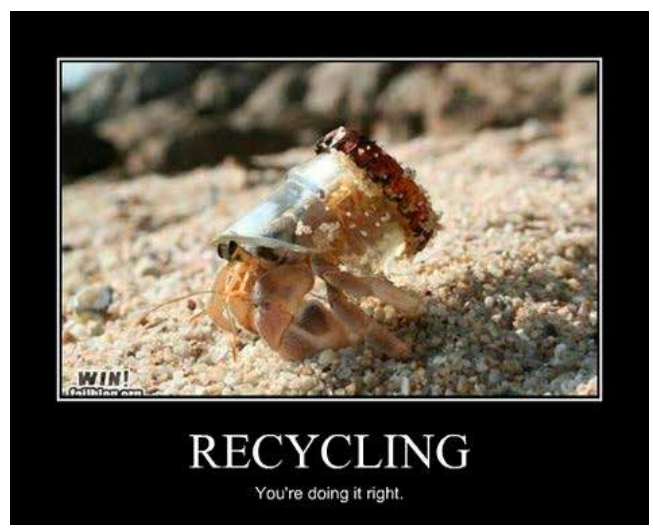

Figure 2: Combination of photo and short text shape the mindsets, forms of behavior, and actions of social groups (Shifman 2014: 18); the cultural information that passes along from person to person gradually scales into a shared social phenomenon. These memes either try to show environmental problems with an attempt to persuade the viewer to behave as a more responsible member of society, or again use waste and dirt as metaphorical elements in the message.

The amount of internet memes on this topic is enormous and they deserve a dedicated study. This article simply outlines a general overview on this view of dirt and waste, and on basic methods memes use to reach the viewers.

Global pollution, the unimaginable quantity of waste, and irresponsible human behavior are such serious topics that internet memes do not use humor by definition; some images are rather 
shocking, or they use creative solutions to describe the problem differently. Memes that emphasize pollution problems often put waste or plastic (which is a large part of today's pollution concept) in the image and use words oriented toward the specific problem of pollution (for example, waste, plastic, cars, straws; or recycling, ecology, etc.).

Internet searches allow for the identification of three main manifestations of meme expressions on various pollution problems. The first type is memes using illustrations and words on the topic (Fig. 1), which also incorporate word games or variations of the titles (Straws vs. Jaws, whale vs. will, etc.).

One of most recognizable images in internet memes about the plastic problem was the National Geographic creative image with a plastic bag portrayed as an iceberg. The image was first published on the cover of National Geographic's "Planet or Plastics?" issue (June 2018), but the image was reused in many cases, always with an ecological note.

The second main type of meme is those with photos of realistic situations with minimal information in words (Fig. 2).

The third type is memes with known characters from the media, famous persons, or generally known images also combined with words (Fig. 3).

Multiple internet memes have adopted a single image, but the changed wordings also changed the message of the meme (Fig. 4). These internet memes use the image to "create the atmosphere," while the wordings specify the message that the meme carries (the messages can be on very different topics).

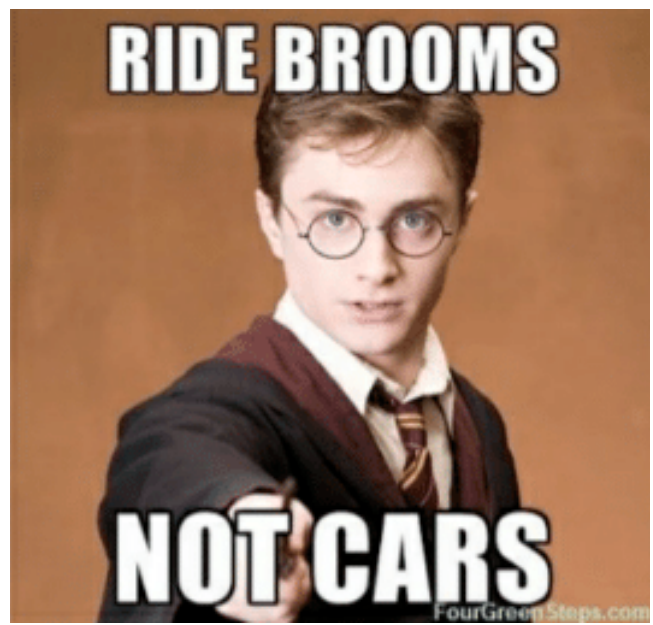

Figure 3: Known character with the words matching the character and the meaning

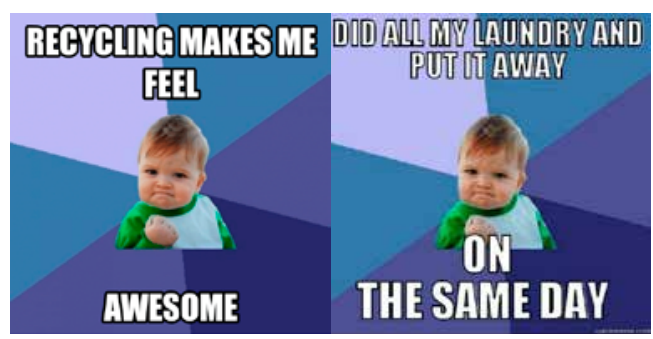

Figure 4: The same image supports the messages of different texts

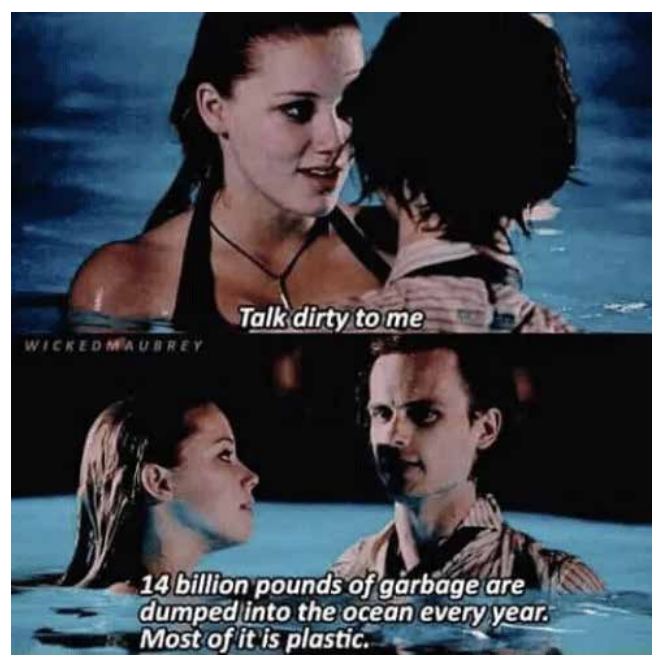

Figure 5: Wordplay with polysemantics 
The metaphorical meanings of dirt and waste are also present in internet memes, and the use of language also mirrors them. Therefore, it is not unusual for internet memes to combine literal and metaphorical meanings. These combinations are usually humorous, and their function is mostly to entertain, not to educate, advise, or inform in any way (in contrast to memes on pollution problems, for example). They mostly play with words (their meaning, prosody, rhyme, etc.) and language in order to make a joke in combination with the image (Fig. 5).

The metaphorical uses of waste, trash, garbage, and dirt use the same conceptual metaphors as in everyday spoken or written language, but internet memes also add humorous images to illustrate the idea.

\section{DISCUSSION}

Dirt and waste are a big part of everyday life, although people try to ignore it: they take waste outside, others take it away from their homes, and waste no longer exists for them. When one thinks of dirt, one might expect that one of the first associations would be hygiene, although Douglas (1984 [1966]) proved that the concepts of dirt mostly denote disorder, and not so much a true hygiene problem. This overview of Slovenian short folklore forms is in accordance with Douglas's concepts regarding the direct meaning of dirt, although the association with dirt is visual dirt like mud or dust (not, for example, invisible bacteria). Visual dirt can be removed by washing, which was also literarily transferred to the ritual of cleaning when the figurative dirt was being outspoken and using inappropriate language.

Just like the concept of dirt mostly denotes disorder, dirt and waste in metaphorical use do so as well: ethnolinguistic research on the use of the metaphorical terms for waste and dirt showed the denomination of redundant, used up, and worn out objects, dirt as an unclean, unwanted characteristic that should be hidden, and cleanliness as a wanted characteristic at all levels, not only physically but also in relationships. These denominations show a dual image in Slovenian: on one hand, the units show that the speakers always understand waste as a redundant, used, or even forgotten thing, but on the other hand it appears in great quantity: waste will never disappear; there will be always too much of it. Through the ethnolinguistic view one can also see precisely what the objects are that are compared to waste and dirt and, as such, they show lower quality (second wife, delayed work, history, etc.). It seems that the attitude expressed toward these objects is the same as that toward trash: they are unappreciated things.

The attitude toward dirt has even induced the connotation of taboo, especially for bodily excretions (which is also explained by Mary Douglas (1984 [1966]) in the ritual context): not only shit as a swear word, but also laundry, which gets dirty from contact with human bodies and should be kept secret, which is transferred to figurative language on disgraceful information about someone or something happening in the family. Body 
parts that can get dirty are either the hands or the mouth. Metaphorically, this is always connected with guilt resulting from a negative or dishonorable action. Although the mouth can be cleaned of dirt (i.e., bad language or bad talk about someone) with washing, the hands cannot be cleaned anymore in the meaning that one does not bear guilt anymore. Only wrong presumptions can be washed away, but never guilt. The "cleanest" metaphorical concept in Slovenian is a tear (sometimes also an eye), which obviously does not go into the same category of bodily excretions as the taboo formations.

Objects that are mentioned in connection with dirt and waste in Slovenian paremias are laundry, brooms, and bowls - these are household objects that were usually used or managed by women. That fact implies that the world of waste and dirt was mostly handled by women and could be discussed in the topic of the social value of gender.

This article focuses mainly on traditional and archival material: phrasemes, proverbs, and beliefs from the ISN archive; that is, traditional forms of folklore. The contemporary internet communication with new forms, which combine different formats in order to reach the viewer, retains the use of the concept of waste and dirt, although they also emphasize environmental and pollution problems. These internet memes try to educate viewers on environmental problems and persuade them to behave as more responsible members of society with creative adaptations of the images, whether drawn, photoshopped, or realistic photography.

The amount of internet memes on this topic is enormous, and they deserve a dedicated study. This article simply outlines a general overview of meme production: what basic methods memes used in describing the problem in order to reach the viewers. However, it seems that newer social problems, such as pollution, obtain a place only in newer folklore forms, whereas the traditional "old forms" persist in a more or less constant repertoire, especially in targeting topics.

\section{CONCLUSION}

Waste and dirt are a large part of life: no matter where or when we live, these phenomena will accompany our existence. The omnipresence of dirt and waste in human society is evident also through language and its forms. Through the ethnolinguistic lens, waste and dirt on all levels_-literal and metaphorical-denote unwanted characteristics, problems, wasted things, or things one wants to hide from the outer world. It is better for dirt to stay behind closed doors, although it could harm us. Cleanliness and purity are the best way to present oneself in the outside world, and new, fresh things are most wanted. Even though the dump or trash can hide something beneficial, it is rare and still of lower quality, and so not really a high priority. The function of these expressions is to express the extremely negative connotation of the message. Not only do people want to hide it, and pretend that the world of dirt and waste does not exist in physical everyday life, they also act similarly on abstract levels: everyone wants to present themselves as clean, fresh, and shiny; immaculate. 
Waste management has also obtained some superstitious characteristics, and performing some actions after sunset was forbidden (as seen in some archival units discussed above). These units are the only ones dealing with household waste management among the archival short folklore forms. On the other hand, in one of the newest short folklore forms, internet memes, waste and pollution problems are highly emphasized. The topic has become one of the most important topics of general interest, and with the new methods of communication waste has also become a large component of folklore forms.

\section{REFERENCES}

Ahearn, Laura M. 2017. Living Language: An Introduction to Linguistic Anthropology. (Second Edition). Malden, MA: Willey Blackwell.

Babič, Saša. 2015. Beseda ni konj: Estetska struktura slovenskih folklornih obrazcev. Ljubljana: Založba ZRC.

Babič, Saša. 2017. Discovering Traffic Phenomena Through Language Analysis. In: Dan Podjed and Simona Bezjak (eds.), Research on the Road: Methodology and Practice of Studying Traffic, Driving Habits, and Sustainable Mobility. Ljubljana: Založba ZRC, 129-149.

Balašova, Elena A. 2004. Naivnaja kartina mira Slovencev: Etnolingvističeskij podhod [Naïve Map of the World in Slovenian: Ethnolinguistic Approach]. In: Erika Kržišnik (ed.), Aktualizacija jezikovnozvrstne teorije na Slovenskem: Členitev jezikovne resničnosti. Ljubljana: Univerza v Ljubljani, 3-18.

Bartmiński, Jerzy. 2005. Jazykovoj obraz mira: Očerkipo etnolingvistike [The Language Image of the World: Articles on Ethnolinguistics]. Moscow: Indarik.

Dancygier, Barbara, and Eve Sweetser. 2014. Figurative Language. New York: Cambridge University Press.

Douglas, Mary. 1984 [1966]. Purity and Danger: An Analysis of the Concepts of Pollution and Taboo. London: Routledge.

Duranti, Alessandro. 1997. Linguistic Anthropology. Cambridge: Cambridge University Press.

Forrester, Michael A. 1996. Psychology of Language: A Critical Introduction. London: Sage Publications.

Frawley, William. 1992. Linguistic Semantics. Hillsdale, NJ: Lawrence Erlbaum Associates.

Georges, Robert A., and Michael Owen Jones. 1995. Folkloristics: An Introduction. Bloomington, IN: Indiana University Press.

Green, Thomas A. (ed.). 1998. Folklore: An Encyclopedia of Beliefs, Customs, Tales, Music, and Art. Santa Barbara, CA: ABC-CLIO.

Knechtel, John. 2007. Introduction. In: John Knechtel (ed.), Trash. Cambridge, MA: MIT Press, 8-9.

Lakoff, George, and Mark Johnson. 1980. Metaphors We Live By. Chicago: University of Chicago Press.

Lizardo, Omar. 2012. The Conceptual Bases of Metaphors of Dirt and Cleanliness in Moral and Non-Moral Reasoning. Cognitive Linguistics 23 (2): 367-393. DOI: https://doi.org/10.1515/cog-2012-0011.

Oring, Elliott. 1976. Three Functions of Folklore: Traditional Functionalism as Explanation in Folkloristics. The Journal of American Folklore 89/351 (Jan.-Mar.): 67-80. Available at: https://www.jstor.org/ stable/i223694

Petrovič, Tanja. 2010. Ideje o jeziku, ideologije v jeziku: Kaj je jezik, ali kaj bi moral biti? Emzin: Revija za kulturo 20/1-2 (Jun.): 55-57. 
Podjed, Dan. 2009. Po sledeh požigalca: Antropološki pogled na spletna družbena omrežja. Glasnik Slovenskega etnološkega društva 49/3-4: 38-46.

Shifman, Limor. 2014. Memes in Digital Culture. London: The MIT Press.

Steen, Gerard J. et al. 2010. A Method for Linguistic Metaphor Identification. Amsterdam: John Benjamins Publishing Company.

Tolstaya, Tatjana. 2015. Obraz mira v tekste i rituale. Moscow: Universitet Dmitrija Požarskogo.

Tolstoi, Nikita I. 1995. Jazyk i narodnaja kul'tura: Očerki poslavjanskoj mifologii i etnolingvistike [Language and National Culture: Articles on Slavic Mythology and Ethnolinguistics]. Moscow: Indarik.

Wittgenstein, Ludwig. 1953. Philosophical Investigations. Oxford: Basil Blackwell.

\section{SMETI IN UMAZANIJA V FOLKLORNIH OBRAZCIH}

Odpadki in umazanija so pomemben del našega življenja: ne glede na to, kje in kdaj živimo, ti spremljajo naše bivanje. Vseprisotnost umazanije in odpadkov v človeški družbi je razvidna tudi $v$ jeziku in njegovih oblikah. Umazanija in odpadki se uporabljajo kot metafore v jezikovnih oblikah na vsakdanji ravni. Etnolingvistični pristop $k$ raziskavam gradiva folklornih obrazcev pokaže, da so odpadki in umazanija na vseh ravneh - dobesedni in metaforični - označujejo neželene lastnosti, težave, zapravljene stvari ali stvari, ki jih želimo skriti pred zunanjim svetom. Umazanija naj raje ostane za zaprtimi vrati, pa čeprav nam to škoduje. Čistoča je edina oblika, ji je lahko predstavljena v zunanjem svetu: nove, sveže stvari pa so najbolj iskane. Čeprav smeti ali odpadki lahko skrivajo v sebi tudi kaj koristnega, so te stvari redke in še vedno slabše kakovosti. Podobno kot skrivamo in se pretvarjamo, da svet umazanije in odpadkov v fizičnem vsakdanjiku ne obstaja, ravnamo tako tudi na abstraktnih ravneh: vsi si želijo biti čisti, sveži in sijoči, brezmadežni.

Ravnanje z odpadki je vstopilo tudi v svet praznoverja: prepovedano je bilo čistiti po sončnem zahodu. Te enote so redke med folklornimi obrazci. Po drugi strani so ena najnovejših kratkih folklornih oblik internetni memi, ki tematizirajo probleme zodpadki in onesnaževanje. Tema je postala ena najpomembnejših v sodobni družbi, zato so z novimi načini komuniciranja tudi odpadki postali velik del folklornih oblik.

Assist. Prof. Dr. Saša Babič, Research Fellow, ZRC SAZU, Institute of Slovenian Ethnology, Novi trg 2, 1000 Ljubljana, Slovenia, sasa.babic@zrc-sazu.si

The author acknowledges the financial support from the Slovenian Research Agency (research project L6-9364 - The Invisible Life of Waste ... and the research program P6-0088). 